Published in the Journal of Homosexuality

65(1): 42-65

http://dx.doi.org/10.1080/00918369.2017.1310550

\title{
Homosexuality, Religion, and the Family: The Effects of Religion on Americans' Appraisals of the Parenting Abilities of Same-Sex Couples
}

Andrew L. Whitehead, MA, PhD

Clemson University

Acknowledgements: The author would like to thank the editor and anonymous reviewers as well as Sam Perry for their comments on an earlier draft of this article. All errors and omissions remain the author's alone. Address correspondence to Andrew L. Whitehead, 132 Bracket Hall, Clemson, SC 29634, USA. E-mail: alw6@ clemson.edu. 


\section{Homosexuality, Religion, and the Family: The Effects of Religion on Americans' Appraisals of the Parenting Abilities of Same-Sex Couples}

While a growing body of research focuses on Americans' attitudes toward same-sex couples as parents, very few include measures of religion and those that do fail to capture its multidimensional nature. Furthermore, many past studies rely on convenience samples of college students, or samples gathered outside the United States. Multivariate analyses of the 2012 General Social Survey - a nationally representative sample of adults in the United States - reveal that a slim majority of Americans still do not believe same-sex couples can parent as well as male-female couples and the religious beliefs, behaviors, and affiliations of Americans are significantly and at times differentially associated with appraisals of same-sex couples' parenting abilities. It appears that while religion is generally associated with more negative appraisals of the parenting abilities of same-sex couples, it is not uniformly so. Americans' immediate religious and cultural context can shape their appraisals of homosexuality in diverse ways.

Keywords: Family, Homosexuality, Religion, Same-sex families, Same-sex parenting, Parenting, United States

Running Header: Homosexuality, Religion, and the Family 
A remarkable body of research focuses on attitudes toward gays and lesbians and all aspects of their lives (same-sex unions and other civil rights) and has grown quickly over the past two decades. This research demonstrates how attitudes toward gays and lesbians continue to shift (Anderson \& Fetner, 2008; Baunach, 2011), and how various predictors like education (Ohlander, Batalova, \& Treas, 2005), race (Sherkat et al., 2010), gender (Barringer, Gay, \& Lynxwiler 2013; Whitehead, 2013a, 2014a), politics (Sherkat et al., 2011), religious beliefs (Perry \& Whitehead, 2016b; Whitehead, 2010; Whitehead \& Perry, 2015b), religious traditions (Adamczyk \& Pitt, 2009; Olson, Cadge, \& Harrison, 2006; Perry \& Whitehead, 2016b; Sherkat, 2014), and religious behavior (Perry \& Whitehead, 2016a; Sherkat et al., 2010; Whitehead, 2014b) are significantly associated with either support or opposition of gays and lesbians and their integration into American society. Given that the debate and legal battle over same-sex unions dominated the legal and political spheres of American society over the past decade, it is no surprise that most research concerns attitudes toward gay marriage. Consistently, religion continues to be one of the strongest predictors of these attitudes (Olson et al., 2006; Perry \& Whitehead, 2016a, 2016b; Sherkat et al., 2010; Sherkat et al., 2011; Whitehead, 2014b).

However, attitudes Americans hold toward gay men and women as parents and religion's association with those attitudes received much less attention. Powell et al. (2009) investigated how Americans define "family" and whether or not same-sex couples both with and without children fit that definition. They found that close to a third of Americans defined same-sex couples without children as a family while around 60 percent of Americans defined same-sex couples with children as a family. Some work examines the extent to which American's support adoption by same-sex couples and religion's relationship with those attitudes (Lambert et al., 2006; Perry, 2013; Perry \& Whitehead, 2016b; Whitehead \& Perry, 2014). While the findings 
from these studies assess aspects of same-sex families, missing from the discussion is an examination of how Americans' view the parenting abilities of same-sex couples. Analyses using samples from Australia or American college students find that gay and lesbian parents are viewed more negatively than heterosexual parents (Crawford \& Solliday, 1996; Herbstrith et al., 2013; King, 2001; King \& Black, 1999; Morse, McLaren, \& McLachlan, 2007). This research provides preliminary evidence that religion is significantly associated with attitudes toward same-sex couples' parenting abilities but their operationalization of religion is limited. The use of only single measures of religion limits our understanding of the varied influence of religion on attitudes toward the parenting abilities of same-sex couples. The multidimensional influence of religion is something broadly and consistently supported in the literature on homosexuality and gay civil rights. The current study fills these significant gaps in the literature and improves upon prior research by not only including a collection of religion measures that account for religion's multidimensional nature but by also examining the mediating and moderating relationships of those measures.

The following analysis of the 2012 General Social Survey - a nationally representative sample of Americans' attitudes - demonstrates that less than half of Americans believe same-sex male and same-sex female couples ${ }^{1}$ can raise a child as well as a male-female couple and that Americans consistently view same-sex male couples as less capable parents compared to samesex female couples. Most importantly, the religious affiliations, beliefs, and behaviors of Americans are vital to explaining these negative appraisals. In fact, some of the religious beliefs

\footnotetext{
${ }^{1}$ This analysis uses the 2012 GSS which only measures Americans' attitudes toward gay and lesbian couples. Because my analysis cannot speak to Americans' views toward bisexual or transgendered Americans, I focus my discussion on "same-sex male" and "same-sex female" couples, as they are referred to in the 2012 GSS, rather than using a broader term like GLBTQ. While this terminology is not ideal, it represents what is being measured in the data source.
} 
and behaviors of Americans interact in such a way that make negative appraisals of the parenting abilities of same-sex male and same-sex female couples even more likely. Others, however, appear to moderate one another subsequently softening negative appraisals of same-sex parents. These findings encourage researchers to acknowledge and account for the vast and varied influence of religion on attitudes toward same-sex family forms.

\section{Attitudes toward Same-Sex Parented Families}

Compared to the large number of studies examining attitudes toward homosexuality and same-sex unions, there is a relative dearth of literature that specifically investigates Americans' attitudes toward same-sex couples' parenting abilities. Powell and colleagues (2009) offer an extensive and systematic look at Americans' definitions of the family. While never directly examining Americans' appraisals of the parenting abilities of same-sex couples, they find that a slight majority of Americans are willing to define same-sex couples with children as a "family." However, they find a significant minority of Americans (38\% in 2006), who they define as “exclusionists," categorically reject same-sex couples with children as being families. Many exclusionists defined family using emotional or relational bonds as the important defining factor, which are not limited to only heterosexual households. However, when pressed on this fact, exclusionists overcame this contradiction by refusing to acknowledge that same-sex couples and families could cultivate these types of "instrumental and expressive bonds" (Powell et al., 2009, p. 47). It appears that the reluctance to define same-sex couples with children as families hinges in part on exclusionists' skepticism of the parenting abilities of same-sex couples.

In addition to examining how Americans define family, a number of researchers examine attitudes toward same-sex adoption (Averett et al., 2011; Besen \& Zicklin, 2007; Lambert et al., 2006; McLeod, Crawford, \& Zechmeister, 1999; Perry, 2013; Ryan Bedard, \& Gertz, 2007; 
Weiner \& Zinner, 2015). A number of these studies examine religion's influence on those attitudes (Kirby \& Michaelson, 2015; Perry \& Whitehead, 2015a, 2015b, 2016b; Whitehead \& Perry, 2014). However, these studies do not directly measure attitudes toward the parenting abilities of gay and lesbian parents and are mostly suggestive of Americans attitudes.

A handful of studies directly investigate peoples' attitudes toward same-sex parents. Using a small convenience sample of college students, Crawford and Solliday (1996) found that students consistently espoused more negative views toward gay couples. In particular, they believed the gay parents would not provide as safe a home or be as emotionally stable as heterosexual parents. McLeod and colleagues (1999) also used a convenience sample of college students and found that students' viewed gay households as more distressing and confusing, even going so far as to recommend revoking custody rights for gay couples. Several studies found that college students' appraisals of lesbian mothers was consistently negative and their negativity partially translated to their children (King, 2001; King \& Black, 1999). Herbstrith and colleagues (2013) discovered that college students training to become teachers tended to rate same-sex couples more negatively than heterosexual couples. The more negative views of college students does not appear to be a solely American phenomenon, either (see Costa et al., 2014). Finally, studies from Australia and Norway using larger samples that do not consist entirely of students and find consistent evidence for more negative appraisals of both gay and lesbian same-sex parents (Hollekim, Slaatten, \& Anderssen, 2012; Morse, McLaren, \& McLachlan 2007).

\section{Religion and Attitudes toward Homosexuality}

Religious Americans are consistently more opposed to homosexuality and equal rights for gays and lesbians. The key overall finding is that religion is associated with these attitudes in a multidimensional and sometimes complicated fashion (Whitley 2009). First, researchers find 
that religious affiliation is significantly associated with more negative views of gays and lesbians. Evangelical and Black Protestants are more opposed to homosexuality than are Mainline Protestants, Catholics, Jews, and the unaffiliated (Adamczyk \& Pitt, 2009; Adler, 2012; Andersen \& Fetner, 2008; Barringer et al. 2013; Perry \& Whitehead, 2016b; Sherkat et al., 2011; Whitehead, 2010, 2013). However, there is substantial diversity within the Evangelical tradition toward gay rights (Bean \& Martinez, 2014).

Second, researchers find that various religious beliefs significantly predict attitudes toward same-sex relationships and homosexuality. Those with traditional religious beliefs like viewing God as masculine or interpreting the Bible literally are much more likely to oppose homosexuality and same-sex relationships (Barringer et al. 2013; Froese et al., 2008; Hill et al., 2004; Perry, 2015; Whitehead, 2010, 2014a; Whitehead \& Perry, 2014). However, prior work also finds variation in the association of different views toward the Bible. Perry (2015) demonstrated that believing the Bible is inspired and/or inerrant results in distinct associations with attitudes toward same-sex marriage. Similarly, when examining support of same-sex adoption, Whitehead and Perry (2014) revealed that Americans who believe the Bible should be interpreted occupy a middle ground of support between biblical literalists - who are less supportive - and those who view the Bible as an ancient book of legends and fables - who are most supportive.

Prior research identifies religious practice as another measurement of religiosity that significantly influences attitudes toward homosexuality. Americans who actively attend religious worship services are more likely to oppose same-sex unions and look negatively upon homosexuality (Andersen \& Fetner, 2008; Barringer et al. 2013; Olson et al., 2006; Perry \& Whitehead, 2016b; Sherkat et al., 2010; Whitehead, 2010, 2014b). Attending religious services 
frequently serves to reinforce religious Americans' plausibility structures (Berger, 1967;

Petersen \& Donnenwerth, 1998). People receive cues concerning proper stances toward homosexuality and those views are supported and strengthened. Since religious congregations are on the whole opposed to homosexuality (Whitehead, 2013b), the majority of people attending religious worship services are receiving negative cues concerning homosexuality. Beyond worship service attendance, other studies show that consistent Bible reading or praying frequently is also associated with negative attitudes toward gays and lesbians (Ellison, Wolfinger, \& Ramos-Wada, 2013; Lubbers et al., 2009). However, Whitehead and Perry (2014) found that while active attendance at religious services and frequent Bible reading were negatively associated with support for adoption by same-sex couples, frequent prayer was not. They suggest that while it is through religious service attendance and scripture reading that traditional religious teachings concerning homosexuality are learned and sustained, prayer does not necessarily expose Americans to negative schemas regarding homosexuality. Therefore, it is not religious activity alone that predisposes Americans to be opposed to homosexuality, but active interaction with sources of "religiocultural schemas that denounce such relationships" (Whitehead \& Perry, 2014, p. 17).

Finally, there is ample evidence that religious belief, behavior, and affiliation at times mediate the others' associations with attitudes toward homosexuality (Burdette et al., 2005; Ellison \& Musick, 1993; Perry \& Whitehead, 2016b; Shulte \& Battle, 2004; Whitehead \& Perry, 2014). Therefore, it is important to include multiple measures of religion to account for its full effect. Furthermore, prior work also demonstrates that religious belief, behavior, and affiliation sometimes moderate one another. In one recent and comprehensive analysis, Perry (2015) skillfully exhibits the intensifying and at times diminishing effect of one measure of religion on 
another as they relate to same-sex marriage attitudes. For instance, he finds that as Americans identify more strongly as religious conservatives, the effect of Bible beliefs decreases in intensity. Taken together, prior work on religion and attitudes toward homosexuality consistently demonstrates the importance of accounting for multiple measures of religion in order to specify its multidimensional and diverse effects. This dovetails with an important finding in qualitative research that there are a variety of religious views toward homosexuality and positing only unidirectional negativity misses some of this diversity (Moon, 2014).

\section{Religion and Attitudes toward Same-Sex Parented Families}

While prior research on attitudes toward same-sex couples as parents firmly establishes that people are generally less affirming of the parenting abilities of gay and lesbian couples, few include a measure of religion. In those that do, religion is consistently associated with more negative views toward the parenting abilities of same-sex couples (Crawford et al., 1999; Costa et al., 2014; Hollekim et al., 2012; McLeod et al., 1999; Morse et al., 2007). However, in these studies religion is usually only operationalized in one particular way. For example, Hollekim and colleagues (2012) measure religion only using a question about how much faith respondents report and Morse et al. (2007) only include a measure of religious importance in multivariate models. Another only examines whether respondents belong to a particular religious group (Costa et al. 2014) and others only utilize religious service attendance (Crawford et al., 1999; McLeod et al., 1999). This is a significant weakness given the multifaceted and diverse relationship religion has with attitudes toward homosexuality and same-sex civil rights, as discussed previously. In particular, when examining attitudes toward same-sex adoption, Whitehead and Perry (2014) find that some measures of religion (like religious service attendance and literal views of the Bible) predict negative attitudes, while others are not 
significantly associated (affiliation, frequency of prayer). They demonstrate that it is not sufficient to "control" for religion using only one measure. In order to truly account for the multifaceted influence of religion on attitudes toward same-sex adoption, researchers must utilize a number of indicators that account for the multiple dimensions of religion (see also Perry \& Whitehead, 2016b).

In order to fill this gap in the literature, the current study utilizes a broader array of religion measures. A complete typology of religious tradition is employed instead of relying on only a single dichotomous measure of religious affiliation. Two measures of religious behavior, one public and the other private, are included in order to examine the influence of engaging in religious activities. Finally, this analysis examines the influence of religious beliefs, something neglected in prior work, using a typology of attitudes toward the Bible. Making use of multiple measures of religion covers the multidimensionality of religion and allows for exploration of the mediating relationships between these measures.

Beyond testing the effects of the various measures of religion, it is also important to follow prior research on religion and homosexuality and examine if and how they moderate one another (Perry 2015). Various measures of religion could have an intensifying effect on attitudes toward the parenting abilities of same-sex couples. It is clear that in order to fully account for the complicated relationships between religion measures, researchers must include interaction terms and investigate the various possible moderating relationships. Therefore, I predict that higher levels of religious service attendance will serve to intensify the negative attitudes biblical literalists have toward gays and lesbians. Alternatively, I predict that the negative effect of religious service attendance will be diminished among those who interpret the Bible, rather than take it word-for-word. 


\section{Data}

In order to systematically examine the influence of religion I utilize data from the 2012 wave of the General Social Survey ${ }^{2}$ (GSS) (Smith et al., 2012) made freely available on the Association of Religion Data Archives (www.theARDA.com). The GSS is a nationally representative sample and is conducted by the National Opinion Research Center (NORC). The GSS is funded by the National Science Foundation and has been fielded biannually since 1994. The 2012 GSS contains 4,820 respondents. Given that the GSS uses rotating modules, the measures used as dependent variables in this study were not asked of the entire sample. I restrict analyses to only those cases with applicable responses for all measures used. The American Association for Public Opinion Research (AAPOR) response rate 5 for the 2012 GSS is $71.4 \%$. In order to focus on the attitudes of non-LGBT Americans, I restrict the analyses to respondents who did not identify as "gay, lesbian or homosexual" or "bisexual."3

\section{Dependent Variables}

Two questions from the 2012 GSS are used to examine Americans' attitudes toward same-sex couples raising children. Each question was asked in the following form: "To what extent do you agree or disagree with the following statements? A same sex female [male] couple can bring up a child as well as a male-female couple." Possible responses for both questions ranged from "Strongly agree" to "Strongly disagree." Responses were recoded so "Agree" and "Strongly agree" = 1 with all other responses coded as 0 . "Don’t know" and "no answer" responses were coded as missing. A significant strength of using these separate dependent variables is that they specify Americans' attitudes toward either same-sex male or same-sex

\footnotetext{
${ }^{2}$ The 2012 GSS is the most recent GSS that asks questions concerning the parenting abilities of same-sex couples.

${ }^{3}$ Those identifying as "gay, lesbian or homosexual" or "bisexual" make up 3.5 percent of the total sample.
} 
female couples. Previous research clearly shows that attitudes toward gay men are more negative than attitudes toward lesbians (Herek, 2002; Kite \& Whitley, 1996).

\section{Independent variables of interest}

In order to test for the effects of religious affiliation, I use a typology of religious traditions developed by Steensland et al. (2000). These categories account for the varied historical trajectories and theological views of the major religious groups in the United States: Evangelical Protestants, Mainline Protestants, Black Protestants, Catholics, Jewish, Other, and no affiliation. Following prior literature Evangelical Protestants are set as the contrast category due to their consistently negative attitudes toward homosexuality.

Two different measures of religious behavior, one public and one private, are included in the analysis. First, religious service attendance asks respondents to share how often in the last year they attended religious services of some kind. Possible responses on the nine point scale range from "Never" to "More than once a week". A second private measure of religious behavior asks respondents about how often they pray. Possible responses on the six point scale range from "Never" to "Several times a day".

Finally, I use a series of dichotomous variables concerning views of the Bible to account for conservative religious beliefs (Franzen \& Griebel, 2013). When asked which statement comes closest to describing feelings about the Bible, respondents could respond with "The Bible is the actual word of God and is to be taken literally, word for word" (Biblical literalist = 1), "The Bible is the inspired word of God but not everything should be taken literally, word for word" (Bible inspired = 1), and "The Bible is an ancient book of fables, legends, history and moral precepts recorded by man" (Bible fables $=1$ ). Given that biblical literalists are consistently the most opposed to homosexuality and same-sex unions, they serve as the contrast category in 
the first set of full models in Tables 2 and 3. However, following Franzen and Griebel's (2013)

recommendations, I rotate the other views of the Bible as the contrast category and display these results in Table 4.

\section{Control variables}

Also included in the analyses are host of control variables. These include age (years), gender $($ female $=1)$, marital status $($ married $=1)$, child $($ ren $)$ in the home $($ one or more children $=$ 1), education level (highest grade completed), income $(<\$ 12,500$, to $>\$ 150,000)$, race (nonwhite $=1)$, political ideology $($ Extremely liberal $=1$, Extremely conservative $=7$ ), political party $(\text { Republican }=1)^{4}$, region $($ South $=1$, Midwest $=1$, West $=1$, East $=$ contrast category $)$, and size of place (rural =1). Gender ideology is measured using an index of three questions concerning attitudes toward women's roles in family and work life $($ Egalitarian $=3$, Traditional $=12)$ : “A working mother can establish just as warm and secure a relationship with her children as a mother who does not work," "A preschool child is likely to suffer if his or her mother works," and "It is much better for everyone involved if the man is the achiever outside the home and the woman takes care of the home and family." Possible responses for all questions ranged from "Strongly agree" to "Strongly disagree". The alpha reliability coefficient for the index is 0.70 and each of these questions is routinely utilized in gender traditionalism scales (see Davis and Greenstein, 2009). Also available in the 2012 GSS are questions concerning the morality of homosexuality, attitudes toward same-sex marriage, and the civil rights of gay men and lesbians. Given the extensive coverage of these measures in prior work on religion and homosexuality, the

\footnotetext{
${ }^{4}$ Additional analyses (available upon request) included a series of dummy variables for the political party measure. A series of models rotated Republican, Democrat, Independent, and Other party as the contrast category. Republicans were always less likely to agree that same-sex couples could raise children as well as male-female couples compared to Democrats and Independents. Democrats and Independents were both more likely to agree same-sex couples could raise children as well as male-female couples compared to Republicans, but were never significantly different from each other. For this reason, I chose to include the Republican measure alone, rather than a series of dichotomous variables, to create a more parsimonious model.
} 
following analysis focuses on the same-sex parenting questions. One goal for future research is to incorporate these measures into additional examinations of religion and attitudes toward samesex parenting.

\section{Methods}

This analysis proceeds through a number of steps. First, I display the descriptive statistics of the sample in Table 1. Tables 2 and 3 contain the multivariate analyses. Table 2 examines attitudes toward same-sex male parents, while Table 3 examines attitudes toward same-sex female parents. Due to the coding of the dependent variables, binary logistic regression models are estimated. In order to account for substantive significance alongside statistical significance, I calculated and present standardized regression coefficients..$^{5}$ In Tables 2 and 3 the models progress as follows: the socio-demographic control variables compose Model 1, Model 2 includes the religious affiliation typology, the typology of religious belief is added to Model 3, and Model 4 - the full model - includes the two measures of public and private religious behavior. Table 4 displays the findings from rotating the contrast category for the religious belief typology. Table 5 contains the results from the interaction effects between the religious belief and religious behavior measures.

To account for missing data on the independent and control variables, I utilize multiple imputation (MI) techniques to avoid potential biases in standard errors (Allison, 2002; Rubin, 1996). The MI procedure generates five imputations using multiple Markov Chains based on all variables included in each model, resulting in an overall $\mathrm{N}$ of 5,945 (1,189 X 5) for the same-sex male parents dataset and an overall $\mathrm{N}$ of 5,950 (1,190 X 5) for the same-sex female parents dataset. All results use the MI dataset. All of the results reported in Tables 2 and 3 are from the

\footnotetext{
${ }^{5}$ Standardized coefficients are estimated as $B_{y x}^{*}=b_{y x}\left(s_{x} / s_{y}\right)$ and we follow Pampel's (2000) assumption that the standard deviation of $\operatorname{logit}(\mathrm{y})=1.8138$.
} 
MIANALYZE procedure in SAS. This procedure combines all of the results from each of the five imputations resulting in overall estimates, standard errors, and significance levels. The standardized coefficients and odds ratios for each model were calculated using these overall estimates. The Proportional Reduction in Error (PRE) reported in Tables 2 and 3 for each model are the average of the PRE for each individual iteration. Before running the MI procedure, I first reduced the dataset to only those cases with full information on one or both of the dependent variables. Because a half dozen individuals answered only one but not the other question concerning same-sex couples raising children, resulting in respondents being missing for one variable but not the other, I created a separate dataset for each dependent variable. The subsequent analyses utilize these separate datasets depending on which dependent variable is in view. The descriptive statistics reported in Table 1 are averages across the two datasets due to their being almost identical. Comparisons of the descriptive statistics for the two data sets are available upon request.

\section{Results}

Comparing the two dependent variables in Table 1 it is apparent that slightly fewer Americans agree that same-sex male couples can raise children as well as a male-female couple compared to same-sex female couples. About 48 percent see same-sex female parents as equal to heterosexual couples, while 44 percent of Americans see same-sex male parents as equal to male-female couples.

\section{[Table 1 about here]}

Table 2 displays the logistic regression models of agreement that same-sex male parents raise children as well as male-female couples. Model 1 includes all of the socio-demographic control variables. 
[Tables 2 and 3 about here]

Model 2 in Tables 2 and 3 includes the religious affiliation measures. Compared to Evangelical Protestants, Catholics and the unaffiliated are both more likely to agree that samesex male and same-sex female couples can raise a child as well as a male-female couple. In the presence of the socio-demographic controls, there are no significant differences between Evangelical Protestants and Mainline Protestants, Black Protestants, and Jewish respondents, respectively. After including the religious affiliation measures, there is very little change in the socio-demographic associations; all of these measures maintain their direction and level of significance except living in a rural area, which fails to attain statistical significance.

Model 3 in Tables 2 and 3 adds in the series of dichotomous variables concerning Bible beliefs. Compared to biblical literalists, respondents who view the Bible as inspired or as a book of fables are all significantly more likely to agree that same-sex male and same-sex female couples can raise a child as well as a male-female couple. Model 4 in Tables 2 and 3 represents the full model in this analysis and includes the two measures of religious practice, religious service attendance and frequency of prayer. In Table 2 and Table 3 religious service attendance is significantly and negatively associated with agreement that same-sex couples (either male or female) can parent as effectively as a male-female couple. Frequency of prayer is not significantly related to views toward the parenting abilities of same-sex male couples (Table 2), once accounting for all other effects. Frequency of prayer is significantly and negatively related to agreement that same-sex female couples can raise children as well as a male-female couple (Table 3). Across Tables 2 and 3, there is little change to the other religion and sociodemographic measures moving from Model 3 to Model 4. Evangelical Protestants are no different from other religious traditions once accounting for all other effects, and biblical 
literalists are less likely to agree that same-sex couples can parent as effectively as a male-female couple compared to those who view the Bible as inspired and those who view the Bible as a book of fables.

Table 4 displays the findings when rotating the contrast category for Bible views in the full model. Franzen and Griebel (2013) demonstrate that each view of the Bible may exhibit a distinct and unique relationship when compared to other views of the Bible. "Bible inspired" is the contrast category in Model 1 in Table 4. Interestingly, Americans who believe the Bible is inspired but should not be read literally are significantly more likely to agree same-sex male parents can raise a child as well as a male-female couple, but are simultaneously less likely to agree compared to Americans who view the Bible as a book of fables. However, regarding Americans' attitudes toward same-sex female couples' parenting abilities, those who view the Bible as inspired are no different from Americans who view the Bible as a book of fables but are significantly more likely to agree same-sex female couples can parent as well as a male-female couple when compared to biblical literalists. A similar trend is apparent when "Bible fables" is the contrast category in Model 2 of Table 4. Americans who believe the Bible is a book of fables are significantly more likely to agree that same-sex male parents can raise a child as well as a male-female couple compared to both biblical literalists and those who believe the Bible is inspired. However, when comparing same-sex female parents and male-female parents Americans who view the Bible as a book of fables are significantly different from biblical literalists, but not from those who view the Bible as inspired.

[Table 4 and 5 about here]

Table 5 displays the results from the religion interaction effects. In line with earlier predictions, some of the religion measures appear to moderate one another. While most do not, 
three show consistent effects when comparing same-sex male parents and same-sex female parents with a male-female couple. Figures 1, 2, and 3 display each of these three significant effects. First, there is a significant and negative interaction between attendance and prayer. Figure 1 displays this interaction graphing the predicted probability of agreement that same-sex couples can raise children as well as a male-female couple. For both same-sex male and samesex female couples, as Americans' religious service attendance and prayer frequency increases, they become even less likely to agree same-sex couples can raise children as well as a malefemale couple. For example, Americans who report religious service attendance and prayer frequency one standard deviation above the mean have a predicted probability of 0.30 of agreeing that same-sex male couples can parent as effectively as a male-female couple, compared to a predicted probability of 0.65 for Americans who report mean levels of religious service attendance and prayer frequency.

[Figure 1 about here]

The other two significant interactions for both same-sex male and same-sex female measures are religious service attendance and biblical literalism as well as religious service attendance and viewing the Bible as inspired (Bible Inspired). ${ }^{6}$ I find that similar to the religious service attendance and prayer interaction, the religious service attendance and biblical literalism interaction is negative. Figure 2 displays how the negative association between religious service attendance and agreement that same-sex couples can raise a child as well as a male-female couple is amplified for those who also identify as a biblical literalist. The interaction effect for

\footnotetext{
${ }^{6}$ It is important to note that the significance level for the attend*biblical literalism interaction term for the same-sex male parents model does not quite clear the standard cut-off of $\mathrm{p}<0.05$. Rather, the $\mathrm{p}$-value is 0.052 . However, because this interaction does at least reach marginal significance $(\mathrm{p}<0.10)$, is only two-thousandths above the standard cut-off $(\mathrm{p}<0.05)$, and reaches significance in the same-sex female parents model $(\mathrm{p}<0.01)$, we draw attention to it here as well as graph it in figure 2.
} 
religious service attendance and viewing the Bible as inspired, however, is positive. As figure 3 shows, viewing the Bible as inspired actually appears to limit the negative effects of religious service attendance on agreement that same-sex couples can parent as well as a male-female couple. Americans who view the Bible as inspired and are one standard deviation above the mean for religious service attendance have a predicted probability of 0.67 of agreeing that samesex female couples can parent as effectively as a male-female couple, while those who do not view the Bible as inspired and who also attend at levels one standard deviation above the mean have a predicted probability of agreement of only 0.48 .

[Figure 2 and 3 about here]

\section{Discussion}

Using a large, nationally representative sample of Americans, the current analysis demonstrates the strong and varied influence of religion on attitudes toward the parenting abilities of same-sex couples. To date, no study fully examines the various avenues through which religion influences Americans' attitudes toward same-sex parents. As prior work points out, knowing how religion is related to same-sex marriage may not translate to how religion is associated with attitudes toward the parenting abilities of same-sex couples (Perry \& Whitehead, 2016b). Furthermore, this study also employs measures that improve upon those used in previous research. Using an expanded collection of religion measures significantly extends the present literature on attitudes toward the parenting abilities of same-sex couples. It is clear that religion does not result in anti-gay prejudice at all times. While religious behavior or particular religious beliefs are usually associated with negative appraisals of same-sex couples' parenting abilities, the immediate cultural context within which religious Americans are embedded can shape those effects and at times diminish them. On occasion, religious behaviors and beliefs do not predict 
negative appraisals at all. As the cultural context in the United States continues to shift toward more inclusive attitudes, future researchers must continue to examine the diverse influence of religion on attitudes toward same-sex family forms.

Once accounting for all of the effects of various socio-demographic indicators and ideological measures, Americans who attend religious services more often are more likely to believe same-sex couples cannot parent as well as male-female couples. Attending these services most likely embeds Americans in particular interpretive communities and provides social support for these specific belief systems (Petersen \& Donnenwerth, 1998; Whitehead \& Perry, 2014). However, some private religious behaviors, like prayer, may not have as consistent an effect as religious service attendance. While greater prayer frequency is associated with negative attitudes toward same-sex female couples' parenting abilities, it has no significant relationship with samesex male couples' parenting abilities. This finding corresponds to previous research that shows private religious behaviors like prayer may not always push Americans toward negative attitudes toward homosexuality (Whitehead \& Perry, 2014). It may be that it is not religious devotion alone that creates and sustains opposition toward same-sex family forms.

Furthermore, Americans who believe the Bible should be read and interpreted literally are also more likely to look derisively on same-sex couples parenting abilities, no matter if the couple is two men or two women. The significant and negative effect of biblical literalism is most likely tapping into particular schemas that organize Americans' worldviews (Burdette et al., 2005; Hill et al., 2004; Sherkat et al., 2010; Sherkat et al., 2011; Whitehead and Perry, 2014) as well as into identities of religious conservatism which are also consistently related to negative attitudes toward same-sex couples and families (Franzen \& Griebel, 2013; Perry, 2015). However, a closer look at the various bible beliefs reveals additional findings, especially 
regarding the difference in Americans' attitudes toward the parenting abilities of same-sex male couples versus same-sex female couples. When examining attitudes toward same-sex male couples, Americans who believe the Bible is inspired appear to inhabit an intermediate area between the negative views of biblical literalists and the more inclusive views of those who believe the Bible is a book of fables. This finding has significant implications given that according to the 2012 GSS, almost 45 percent of Americans report believing the Bible is inspired but should not be read literally. Their views of same-sex male parents might be much more amenable to shifts in the positive direction.

However, for attitudes toward same-sex female couples' parenting abilities, it appears that those who believe the Bible is inspired are already more accepting given that there are no significant differences between that group and those who believe the Bible is a book of fables. There is a much clearer split between biblical literalists and everyone else. This fine-grained analysis of religious beliefs underscores the importance of utilizing multiple measures of not only religion, but also the various aspects of religion like belief and behavior. Finally, the results suggest that any differences between religious traditions concerning attitudes toward the parenting abilities of same-sex couples is actually due to differences in the religious behaviors and beliefs present across those traditions. It may be, however, that the influence of religious tradition is much more indirect, funneled through the various religious beliefs and religious behaviors those traditions tend to encourage. Future research could examine this possibility. In addition to highlighting the mediating effects of various measures of religion, the current study also emphasizes the moderating relationships between the religion variables. It is clear that the interaction of religious belief and behavior serves to both intensify and diminish their various direct effects. Americans who consistently practice their faith both publically 
(religious service attendance) and privately (prayer) are most likely to espouse negative views of the parenting abilities of same-sex couples. While religious service attendance has a consistent negative effect, private devotional behaviors like prayer appear to intensify that effect. Similarly, identifying as a biblical literalist appears to further intensify the negative effect of religious service attendance on attitudes toward same-sex couples' parenting abilities. However, the moderating relationships among religion variables is not uniform. As the interaction depicted in Figure 3 demonstrates, viewing the Bible as inspired but in need of interpretation diminishes the strong negative effect that religious service attendance has on attitudes toward the parenting abilities of same-sex couples. This suggests that since a large swath of Americans' hold the interpretivist position, the predicted negative effects of high religious service attendance across that population will be somewhat mitigated. This could lead to further liberalization within various segments of society, even those that "look" highly religious.

In addition to filling the religion gap in the present literature, the current study also significantly improves on past studies by using a nationally representative sample of American adults. Prior research on Americans' attitudes toward same-sex couples' parenting abilities is dominated by the use of convenience samples of college students providing obviously useful, but still suggestive, findings (Costa et al., 2014; Crawford \& Solliday, 1996; Herbstrith et al., 2013; King, 2001; King \& Black, 1999; McLeod et al., 1999). The present analysis is generalizable to the United States adult population. Therefore, the influence of gender, age, political ideology, and gender ideology warrant mention. When examining attitudes toward both same-sex male and female couples, across each model, traditional gender ideology consistently exhibits the strongest negative association. Even when accounting for the varied influence of religion, the standardized coefficient is hardly influenced. Women are also more likely to look favorably on the parenting 
abilities of same-sex couples. These findings concerning gender and gender ideology complement prior studies (Herek, 2002; Kite \& Whitley, 1996; Whitehead, 2014a). Political party, and to a lesser extent political ideology, also exhibit consistent negative associations across all models. Political affiliations and ideologies can in many ways operate as political schemas that motivate actions and attitudes toward gay couples and their parenting abilities (Sherkat et al., 2011). Finally, age and region of the country maintain significant associations once accounting for all other variables. These findings should be used by future researchers as a starting point for continued examinations into the demographic and ideological correlates of positive or negative assessments of same-sex couples' parenting abilities.

In addition to these results, it is important to note the limitations of this study. As with all cross-sectional data, I cannot determine the causal order of effects. It may be that positive and negative appraisals of same-sex couples' parenting abilities precede gender ideology, religious belief, behavior, and affiliation, and politics. Following prior research, however, for most Americans religious belief, behavior, and affiliation tend to crystallize before their attitudes toward same-sex couples' parenting skills relative to male-female couples. If possible, future research on this topic could employ data with two or more time points to account for shifts in attitudes alongside changes in religiosity. Also, due to limitations in the questions asked in the 2012 GSS, I am unable to account for the influence of Americans' beliefs about the cause of homosexuality on their views toward the parenting abilities of same-sex couples. Americans' attribution beliefs have been found to be predictive of attitudes toward same-sex unions and homosexuality in prior studies (Haider-Markel \& Joslyn, 2008; Whitehead, 2010, 2014b). An additional limitation concerns the specificity of the questions concerning same-sex parenting that were available on the 2012 GSS. For instance, Massey, Merriwether, and Garcia 
(2013) find that evaluations of same-sex and opposite-sex parents tends to be quite similar when they engage in positive parenting behaviors. The results of this analysis should be interpreted with caution in light of this prior work. It may be that additional information or multidimensional measures about the parenting behaviors of same-sex couples could influence respondents' attitudes (Massey, 2009). ${ }^{7}$ Future research should continue to explore these relationships including how religious individuals respond to various parenting behaviors depending on whether the couple is same- or opposite-sex.

\section{Conclusion}

In spite of the quickly growing acceptance of homosexuality in the United States over the last decade, a slim majority of Americans still do not evaluate same-sex male and same-sex female couples as equally capable parents when compared to male-female couples. Using a nationally representative sample of American adults, I find that religion plays a significant role in structuring those attitudes. Furthermore, the various manifestations of religion serve to both mediate and moderate one another. Prior research that only included a single measure of religion overlooked the varied effects of religious belief, behavior, and affiliation. As gays and lesbians only recently gained legal rights regarding marriage, future research should continue to pay attention to how Americans evaluate same-sex parented families and relationships. It may very well be that those traditionally opposed to homosexuality who primarily fought against the legal recognition of gay and lesbian relationships may "give up" that fight, only to entrench themselves more deeply in negative appraisals of same-sex family forms. Given the diverse influence of religion on appraisals of same-sex couples' parenting abilities, some sectors of society may be able to successfully maintain their views in spite of larger societal shifts toward

\footnotetext{
${ }^{7}$ I am thankful to a reviewer for this important point.
} 
acceptance of same-sex family forms. However, these analyses also provide evidence that some religious people may be more amenable to positive shifts in attitudes toward same-sex parents. Further study of this possibility is an important task for future research. 


\section{References}

Adamczyk, A. \& Pitt, C. (2009). Shaping attitudes about homosexuality: The role of religion and cultural context. Social Science Research, 38(2), 338-351.

Adler, G. (2012). An opening in the congregational closet? Boundary-bridging culture and membership privileges for gays and lesbians in Christian religious congregations. Social Problems, 59(2), 177-206.

Allison, P. (2001). Logistic regression using the SAS system: Theory and application. New York, NY: John Wiley.

Andersen, R. \& Fetner, T. (2008). Cohort differences in tolerance of homosexuality: Attitudinal change in Canada and the United States, 1981-2000. Public Opinion Quarterly, 72, 31130.

Averett, P., Strong-Blakeney, A., Nalavany, B., \& Ryan, S. (2011). Adoptive parents' attitudes towards gay and lesbian adoption. Journal of GLBT Family Studies, 7, 30-48.

Barringer, M. N., Gay, D. A., \& Lynxwiler, J. P. (2013). Gender, religiosity, spirituality, and attitudes toward homosexuality. Sociological Spectrum, 33, 240-257.

Baunach, D. M. (2011). Decomposing trends in attitudes toward gay marriage, 1988-2006. Social Science Quarterly, 92(2), 357-374.

Bean, L. \& B. C. Martinez. (2014). Evangelical ambivalence toward gays and lesbians. Sociology of Religion, 75(3), 395-417.

Berger, P. L. (1967). The sacred canopy: elements of a sociological theory of religion. New York, NY: Anchor Books.

Besen, Y., \& Zicklin, G. (2007). Young men, religion, and attitudes towards homosexuality. Journal of Men, Masculinities, and Spirituality, 1, 250-66. 
Burdette, A., Ellison, C., \& Hill, T. (2005). Conservative Protestantism and tolerance toward homosexuals: An examination of potential mechanisms. Sociological Inquiry, 75, 177-96.

Costa, Pedro Alexandre, Almeida, R., Anselmo, C., Ferreira, A., Pereira, H., \& Leal, I. (2014). University Students' Attitudes toward same-sex parenting and gay and lesbian rights in Portugal. Journal of Homosexuality, 61(12), 1677-1686.

Crawford, I. \& Solliday, E. (1996). The attitudes of undergraduate college students toward gay parenting. Journal of Homosexuality, 40(3), 63-77.

Crawford, I., McLeod, A., Zamboni, B. D., \& Jordan, M. B. (1999). Psychologists' attitudes toward gay and lesbian parenting. Professional Psychology: Research and Practice, 30(4), 394-401.

Davis, S. N., \& Greenstein, T. N. (2009). Gender ideology: components, predictors, and consequences. Annual Review of Sociology, 35, 87-105.

Doan, L., Miller, L. R., \& Loehr, A. (2015). The Power of Love: The role of emotional attributions and standards in heterosexuals' attitudes toward lesbian and gay couples. Social Forces, 94(1), 401-425.

Ellison, C., \& Musick, M. (1993). Southern intolerance: A fundamentalist effect? Social Forces, 72, 379-98.

Ellison, C., Wolfinger, N., \& Ramos-Wada, A. (2013). Attitudes toward marriage, divorce, cohabitation, and casual sex among working-age Latinos: Does religion matter? Journal of Family Issues, 34, 295-322.

Franzen, A. B. \& Griebel, J. (2013). Understanding a cultural identity: The confluence of education, politics, and religion within the American concept of biblical literalism. Sociology of Religion, 74(4), 521-543. 
Froese, P., Bader, C. D., \& Smith, B. (2008). Political tolerance and God's wrath in the United States. Sociology of Religion, 69(1), 29-44.

Haider-Markel, D. P., \& Joslyn, M. R. (2008). Beliefs about the origins of homosexuality and support for gay rights: An empirical test of attribution theory. Public Opinion Quarterly, $72,291-310$.

Herbstrith, J. C., Tobin, R. M., Hesson-McInnis, M. S., \& Schneider, W. J. (2013). Preservice Teacher Attitudes toward gay and lesbian parents. School Psychology Quarterly, 28(3), 183-194.

Herek, G. M. (2002). Gender gaps in public opinion about lesbians and gay men. The Public Opinion Quarterly, 66, 40-66.

Hill, T. D., Moulton, B. E., \& Burdette, A. M. (2004). Conservative Protestantism and attitudes toward homosexuality: Does political orientation mediate this relationship? Sociological Focus, 37, 59-70.

Hollekim, R., Slaatten, H., \& Anderssen, N. (2012). A Nationwide study of Norwegian beliefs about same-sex marriage and lesbian and gay parenthood. Sexuality Research and Social Policy, 9, 15-30.

King, B. R. (2001). Ranking the stigmatization toward lesbians and their children and the influence of perceptions of controllability of homosexuality. Journal of Homosexuality, 41(2), 77-97.

King, B. R. \& Black, K. N. (1999). Extent of Relational stigmatization of lesbians and their children by heterosexual college students. Journal of Homosexuality, 37(2), 65-81.

Kirby, B. J. \& Michaelson, C. (2015). Comparative morality judgments about lesbians and gay men teaching and adopting children. Journal of Homosexuality, 62, 33-50. 
Kite, M. E. \& Whitley, B. E. (1996). Sex differences in attitudes toward homosexual persons, behaviors, and civil rights: A meta-analysis. Personality and Social Psychology Bulletin, 22(4), 336-353.

Lambert, E. G., Ventura, L. A., Hall, D. E., \& Cluse-Tolar, T. (2006). College students' views on gay and lesbian issues. Journal of Homosexuality, 50, 1-30.

Lubbers, M., Jaspers, E., \& Ultee, W. (2009). Primary and secondary socialization impacts on support for same-sex marriage after legalization in the Netherlands. Journal of Family Issues, 30, 1714-1745.

Massey, S. G. (2009). Polymorphous prejudice: Liberating the measurement of heterosexuals' attitudes toward lesbians and gay men. Journal of Homosexuality, 56, 147-172.

Massey, S. G., Merriwether, A. M., \& Garcia, J. R. (2013). Modern prejudice and same-sex parenting: Shifting judgments in positive and negative parenting situations. Journal of GLBT Family Studies, 9, 129-151.

McLeod, A. C., Crawford, I., \& Zechmeister, J. (1999). Heterosexual undergraduates' attitudes toward gay fathers and their children. Journal of Psychology and Human Sexuality, 11, 43-62.

Moon, Dawne. (2014). Beyond the dichotomy: Six religious views of homosexuality. Journal of Homosexuality, 61, 1215-1241.

Morse, C. N., McLaren, S., \& McLachlan, A. J. (2007). The Attitudes of Australian heterosexuals toward same-sex parents. Journal of GLBT Family Studies, 3(4), 425-455.

Ohlander, J., Batalova, J., \& Treas, J. (2005). Explaining educational influences on attitudes toward homosexual relations. Social Science Research, 34(4), 781-799.

Olson, L. R., Cadge, W., \& Harrison, J. T. (2006). Religion and public opinion about same-sex marriage. Social Science Quarterly, 87, 340-60. 
Pampel, F. C. (2000). Logistic regression: A primer. Thousand Oaks, CA: Sage.

Perry, S. L. (2013). Multiracial church attendance and support for same-sex romantic and family relationships. Sociological Inquiry, 83, 259-85.

Perry, S. L. (2015). Bible beliefs, conservative religious identity, and same-sex marriage support: Examining main and moderating effects. Journal for the Scientific Study of Religion, 54(4), 792-813.

Perry, S. L. \& Whitehead, A. L. (2015a). Same-Sex Adoption as a Welfare Alternative? Conservatism, Neoliberal Values, and Support for Adoption by Same-Sex Couples. Journal of Homosexuality, 62(12), 1722-1745.

Perry, S. L. \& Whitehead, A. L. (2015b). Christian Nationalism, Racial Separatism, and Family Formation: Attitudes toward Transracial Adoption as a Test Case. Race and Social Problems, 7(2), 123-134.

Perry, S. L. \& Whitehead, A. L. (2016a). Religion and non-traditional families in the United States. Sociology Compass 10, 391-403.

Perry, S. L. \& Whitehead, A. L. (2016b). Religion and public opinion toward same-sex relations, marriage, and adoption: Does the type of practice matter? Journal for the Scientific Study of Religion, doi: 10.1111/jssr.12215.

Petersen, L. R., \& Donnenwerth, G. V. (1998). Religion and declining support for traditional beliefs about gender roles and homosexual rights. Sociology of Religion, 59, 353-371.

Rubin, D. B. (1996). Multiple imputation after 18+ years. Journal of the American Statistical Association, 91(434), 473-489.

Ryan, S., Bedard, L., \& Gertz, M. (2007). The influence of gender on the placement of children with gay or lesbian adoptive parents. Journal of GLBT Family Studies, 3, 15-34. 
Powell, B., Bolzendahl, C., Geist, C., \& Steelman, L. C. (2009). Counted out: Same-sex relations and Americans' definitions of family. New York, NY: Sage.

Schulte, L., \& Battle, J. (2004). The relative importance of ethnicity and religion in predicting attitudes towards gays and lesbians. Journal of Homosexuality, 47, 127-42.

Sherkat, D. E. (2014). Changing Faith: The Dynamics and Consequences of Americans' Shifting Religious Identities. New York, NY: New York University Press.

Sherkat, D. E., Mattias de Vries, K., \& Creek, S. (2010). Race, religion, and opposition to samesex marriage. Social Science Quarterly, 91(1), 80-98.

Sherkat, D. E., Powell-Williams, M., Maddox, G., \& Mattias de Vries, K. (2011). Religion, politics, and support for same-sex marriage in the United States, 1988-2008. Social Science Research, 40, 167-180.

Smith, T. W., Hout, M., \& Marsden, P. V. General Social Survey, 1972-2012 [Cumulative File]. ICPSR34802-v1. Storrs, CT: Roper Center for Public Opinion Research, University of Connecticut /Ann Arbor, MI: Inter-university Consortium for Political and Social Research [distributors], 2013-09-11. http://doi.org/10.3886/ICPSR34802.v1

Steensland, B., Park, J. Z., Regnerus, M. D., Robinson, L. D., Wilcox, W. B., \& Woodberry, R. D. (2000). The measure of American religion: Toward improving the state of the art. Social Forces, 79(1), 291-318.

Weiner, B. A. \& Zinner, L. (2015). Attitudes toward straight, gay male, and transsexual parenting. Journal of Homosexaulity, 62, 327-339.

Whitehead, A. L. (2010). Sacred rites and civil rights: Religion's effect on attitudes toward same-sex unions and the perceived cause of homosexuality. Social Science Quarterly, 91, 63-78. 
Whitehead, A. L. (2013a). Gendered organizations and inequality regimes: Gender, homosexuality, and inequality within religious congregations. Journal for the Scientific Study of Religion, 52(3), 476-493.

Whitehead, A. L. (2013b). Religious organizations and homosexuality: The acceptance of gays and lesbians in American congregations. Review of Religious Research, 55, 297-317.

Whitehead, A. L. (2014a). Male and female He created them: Gender traditionalism, masculine images of god, and attitudes toward same-sex unions. Journal for the Scientific Study of Religion, 53(3), 479-496.

Whitehead, A. L. (2014b). Politics, religion, attribution theory, and attitudes toward same-sex unions. Social Science Quarterly, 95(3), 701-718.

Whitehead, A. L. \& Perry, S. L. (2016). Religion and support for adoption by same-sex couples: The relative effects of religious tradition, practices, and beliefs. Journal of Family Issues, 37(6), 789-813.

Whitehead, A. L. \& Perry, S. L. (2015). A more perfect union? Christian nationalism and support for same-sex unions. Sociological Perspectives, 58(3), 422-440.

Whitely, B. E. Jr. (2009). Religiosity and attitudes toward lesbians and gay men: A metaanalysis. The International Journal for the Psychology of Religion, 19, 21-38. 
Table 1: Descriptive Statistics

\begin{tabular}{|c|c|c|c|}
\hline Variables & Description & $\begin{array}{c}\text { Mean or } \\
\%\end{array}$ & $\mathrm{SD}$ \\
\hline Same-sex Male Parents & $\begin{array}{l}1=\mathrm{SA} / \mathrm{A} \text { they can bring up child as well as } \\
\text { male-female couple }\end{array}$ & $44.0 \%$ & --- \\
\hline Same-sex Female Parents & $\begin{array}{l}1=\mathrm{SA} / \mathrm{A} \text { they can bring up child as well as } \\
\text { male-female couple }\end{array}$ & $47.8 \%$ & --- \\
\hline \multicolumn{4}{|l|}{ Religion } \\
\hline Evangelical Protestant & 1= Evangelical & $24.6 \%$ & --- \\
\hline Mainline Protestant & $1=$ Mainline & $11.4 \%$ & --- \\
\hline Black Protestant & $1=$ Black Protestant & $6.1 \%$ & --- \\
\hline Catholic & $1=$ Catholic & $26.8 \%$ & --- \\
\hline Jewish & $1=$ Jewish & $1.8 \%$ & --- \\
\hline Other & $1=$ Other & $6.3 \%$ & --- \\
\hline None & $1=$ unaffiliated & $23.1 \%$ & --- \\
\hline Biblical Literalist & $1=$ Biblical literalist & $30.8 \%$ & --- \\
\hline Bible Inspired & $1=$ Bible inspired, not to be read literally & $44.7 \%$ & --- \\
\hline Bible Fables & $1=$ Bible is a book of fables & $23.0 \%$ & --- \\
\hline Bible Other & $1=$ Other view of Bible & $1.6 \%$ & --- \\
\hline $\begin{array}{l}\text { Religious Service } \\
\text { Attendance }\end{array}$ & $0=$ Never to $8=$ More than once a week & 3.5 & 3.0 \\
\hline $\begin{array}{l}\text { Freq. of Prayer } \\
\text { Socio-demographics }\end{array}$ & $1=$ Never to $6=$ Several times a day & 4.1 & 1.9 \\
\hline Age & In years, $18-99$ & 42.8 & 18.9 \\
\hline Female & $1=$ Female & $52.0 \%$ & --- \\
\hline Married & $1=$ Married & $48.7 \%$ & --- \\
\hline Children & $1=$ Child(ren) in home & $65.0 \%$ & --- \\
\hline Education & In years, $0-20$ & 13.5 & 3.23 \\
\hline Income & $1=<\$ 12,500$ to $11=>\$ 150,000$ & 5.8 & 3.3 \\
\hline Non-White & $1=$ Non-white & $26.8 \%$ & --- \\
\hline East & $1=$ East & $16.4 \%$ & \\
\hline South & $1=$ South & $35.4 \%$ & --- \\
\hline Midwest & $1=$ Midwest & $22.8 \%$ & --- \\
\hline West & $1=$ West & $25.5 \%$ & --- \\
\hline Rural & $1=$ Rural & $9.0 \%$ & --- \\
\hline Conservative Political Id. & $\begin{array}{l}1=\text { Extremely liberal to } 7=\text { Extremely } \\
\text { Conservative }\end{array}$ & 4.1 & 1.5 \\
\hline Republican & $1=$ Republican & $32.4 \%$ & --- \\
\hline $\begin{array}{l}\text { Traditional Gender } \\
\text { Ideology }\end{array}$ & Summed scale, Range 3 to $12(\alpha=0.70)$ & 6.5 & 2.0 \\
\hline
\end{tabular}

Source: 2012 General Social Survey (weighted data) 
Homosexuality, Religion, and the Family

Table 2: Logistic Regression of Agreement that Same-sex Male Parents Raise Child(ren) as Well as Male-Female Couples

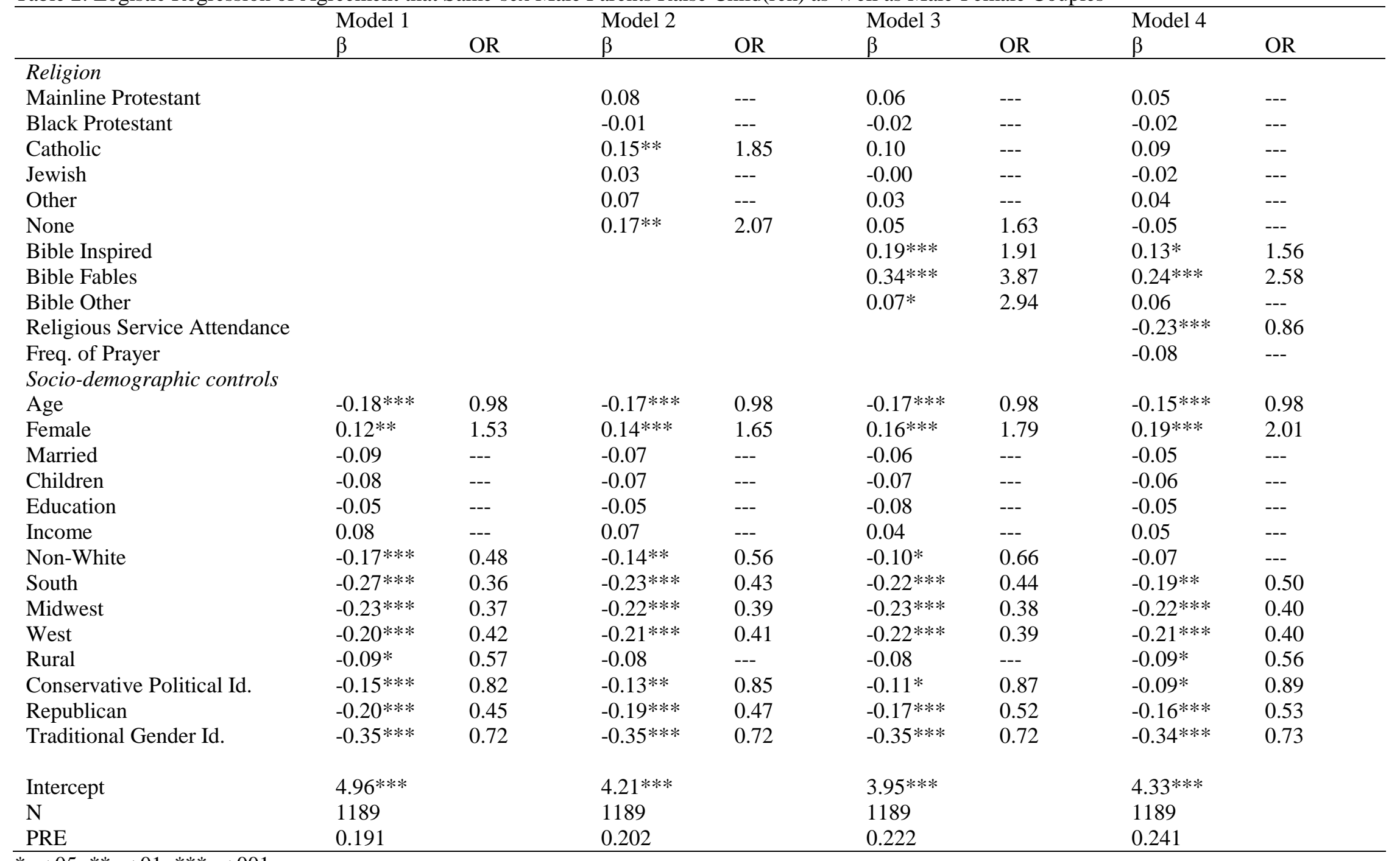

*p<.05;**p<.01;***p<.001

$\beta=$ Standardized Coefficient; OR = Odds Ratio

PRE $=$ Proportional Reduction in Error (Likelihood Ratio/-2 Log Likelihood)

Note: East, Evangelical Protestant, and Biblical Literalist are contrast categories 
Homosexuality, Religion, and the Family

Table 3: Logistic Regression of Agreement that Same-sex Female Parents Raise Child(ren) as Well as Male-Female Couples

\begin{tabular}{|c|c|c|c|c|c|c|c|c|}
\hline & \multicolumn{2}{|l|}{ Model 1} & \multicolumn{2}{|l|}{ Model 2} & \multicolumn{2}{|l|}{ Model 3} & \multicolumn{2}{|l|}{ Model 4} \\
\hline & $\beta$ & OR & $\beta$ & OR & $\beta$ & OR & $\beta$ & OR \\
\hline \multicolumn{9}{|l|}{ Religion } \\
\hline Mainline Protestant & & & 0.09 & --- & 0.07 & --- & 0.05 & --- \\
\hline Black Protestant & & & -0.01 & --- & -0.01 & --- & -0.03 & --- \\
\hline Catholic & & & $0.16 * *$ & 1.95 & $0.11 *$ & 1.57 & 0.10 & --- \\
\hline Jewish & & & 0.06 & --- & 0.02 & --- & 0.00 & --- \\
\hline Other & & & $0.09 *$ & 2.07 & 0.05 & --- & 0.06 & --- \\
\hline None & & & $0.18 * *$ & 2.14 & 0.07 & --- & -0.04 & --- \\
\hline Bible Inspired & & & & & $0.20 * * *$ & 2.04 & $0.14 * *$ & 1.69 \\
\hline Bible Fables & & & & & $0.29 * * *$ & 3.62 & $0.19 * *$ & 2.33 \\
\hline Bible Other & & & & & 0.06 & --- & 0.04 & --- \\
\hline Religious Service Attendance & & & & & & & $-0.18 * * *$ & 0.89 \\
\hline Freq. of Prayer & & & & & & & $-0.14 *$ & 0.87 \\
\hline \multicolumn{9}{|l|}{ Socio-demographic controls } \\
\hline Age & $-0.18 * * *$ & 0.98 & $-0.17 * * *$ & 0.98 & $-0.16 * * *$ & 0.98 & $-0.14 * *$ & 0.99 \\
\hline Female & $0.08 *$ & 1.34 & $0.11 * *$ & 1.47 & $0.13 * *$ & 1.58 & $0.16 * * *$ & 1.79 \\
\hline Married & $-0.11 * *$ & 0.66 & $-0.11 *$ & 0.68 & $-0.09 *$ & 0.72 & -0.08 & --- \\
\hline Children & -0.04 & --- & -0.04 & --- & -0.03 & --- & -0.02 & --- \\
\hline Education & -0.04 & --- & -0.05 & --- & -0.09 & --- & -0.05 & --- \\
\hline Income & 0.08 & --- & 0.07 & --- & 0.04 & --- & 0.05 & --- \\
\hline Non-White & $-0.18 * * *$ & 0.47 & $-0.14 * *$ & 0.56 & $-0.10 *$ & 0.66 & -0.07 & --- \\
\hline South & $-0.24 * * *$ & 0.40 & $-0.20 * * *$ & 0.47 & $-0.19 * * *$ & 0.49 & $-0.16 * *$ & 0.55 \\
\hline Midwest & $-0.20 * * *$ & 0.43 & $-0.19 * * *$ & 0.45 & $-0.20 * * *$ & 0.43 & $-0.18 * * *$ & 0.46 \\
\hline West & $-0.20 * * *$ & 0.42 & $-0.20 * * *$ & 0.42 & $-0.22 * * *$ & 0.39 & $-0.22 * * *$ & 0.40 \\
\hline Rural & $-0.08 *$ & 0.61 & -0.06 & --- & -0.07 & --- & $-0.09 *$ & 0.59 \\
\hline Conservative Political Id. & $-0.15 * * *$ & 0.82 & $-0.13 * *$ & 0.85 & $-0.11 *$ & 0.87 & $-0.09 *$ & 0.89 \\
\hline Republican & $-0.22 * * *$ & 0.42 & $-0.20 * * *$ & 0.45 & $-0.19 * * *$ & 0.48 & $-0.19 * * *$ & 0.48 \\
\hline Traditional Gender Id. & $-0.35 * * *$ & 0.72 & $-0.35 * * *$ & 0.72 & $-0.35 * * *$ & 0.72 & $-0.34 * * *$ & 0.73 \\
\hline Intercept & $5.10 * * *$ & & $4.34 * * *$ & & $4.05 * * *$ & & $4.60 * * *$ & \\
\hline $\mathrm{N}$ & 1190 & & 1190 & & 1190 & & 1190 & \\
\hline PRE & 0.185 & & 0.198 & & 0.218 & & 0.234 & \\
\hline
\end{tabular}

*p<.05;**p<.01;***p<.001

$\beta=$ Standardized Coefficient; $\mathrm{OR}=$ Odds Ratio

PRE $=$ Proportional Reduction in Error (Likelihood Ratio/-2 Log Likelihood)

Note: East, Evangelical Protestant, and Biblical Literalist are contrast categories 
Table 4: Rotating the Contrast Category for Views of the Bible

\begin{tabular}{lcccc}
\hline & \multicolumn{2}{c}{ Same-Sex Male Parents } & \multicolumn{2}{c}{ Same-Sex Female Parents } \\
\cline { 2 - 5 } Model 1 & $\beta$ & OR & $\beta$ & OR \\
\hline Biblical Literalist & $-0.12^{*}$ & 0.64 & $-0.13^{* *}$ & 0.59 \\
Bible Fables & $0.12^{*}$ & 1.65 & 0.07 & --- \\
Bible Other & 0.03 & ---- & 0.00 & \\
& & & & 0.43 \\
Model 2 & & & $-0.22^{* *}$ & --- \\
\hline Biblical Literalist & $-0.25^{* * *}$ & 0.38 & -0.09 & --- \\
Bible Inspired & $-0.15^{*}$ & 0.60 & -0.02 & \\
Bible Other & -0.01 & --- & &
\end{tabular}

$* \mathrm{p}<.05 ; * * \mathrm{p}<.01 ; * * * \mathrm{p}<.001$

$\beta=$ Standardized Coefficient; $\mathrm{OR}=$ Odds Ratio

Note: Results for each model includes all measures from full model in Tables 2 and 3. Contrast category for Model 1 is "Bible Inspired" group; contrast category for Model 2 is "Bible Fables" group. Full model results available upon request.

Table 5: Interaction Effects for Religion Measures

\begin{tabular}{lcccc}
\hline & \multicolumn{2}{c}{ Same-Sex Male Parents } & \multicolumn{2}{c}{ Same-Sex Female Parents } \\
\cline { 2 - 5 } & \multicolumn{1}{c}{$\beta$} & OR & $\beta$ & OR \\
\hline $\begin{array}{l}\text { Attend*Biblical } \\
\text { Literalism }\end{array}$ & $-0.18 \dagger$ & 0.89 & $-0.25^{* *}$ & 0.85 \\
$\begin{array}{l}\text { Attend*Bible } \\
\text { Inspired }\end{array}$ & $0.16^{*}$ & 1.13 & $0.16^{*}$ & 1.13 \\
$\begin{array}{l}\text { Attend*Bible } \\
\text { Fables }\end{array}$ & 0.09 & --- & $0.12^{*}$ & 1.23 \\
Attend*Prayer & $-0.43^{*}$ & 0.95 & $-0.52^{* *}$ & 0.94 \\
$\begin{array}{l}\text { Prayer*Biblical } \\
\text { Literalism }\end{array}$ & -0.05 & --- & -0.11 & --- \\
$\begin{array}{l}\text { Prayer*Bible } \\
\text { Inspired }\end{array}$ & 0.13 & --- & 0.08 & -- \\
Prayer*Bible & 0.08 & --- & $0.16^{*}$ & 1.24 \\
Fables & & & & \\
\hline
\end{tabular}

$\dagger \mathrm{p}=.052 ; * \mathrm{p}<.05 ; * * \mathrm{p}<.01 ; * * * \mathrm{p}<.001$

$\beta=$ Standardized Coefficient; OR = Odds Ratio

Note: Each interaction was included in a separate full model. Results for each full model available upon request. 
Figure 1: Predicted Probability of Agreement that Same-Sex Couples Raise Children as Well as Male-Female Couples by Religious Service Attendance and Frequency of Prayer

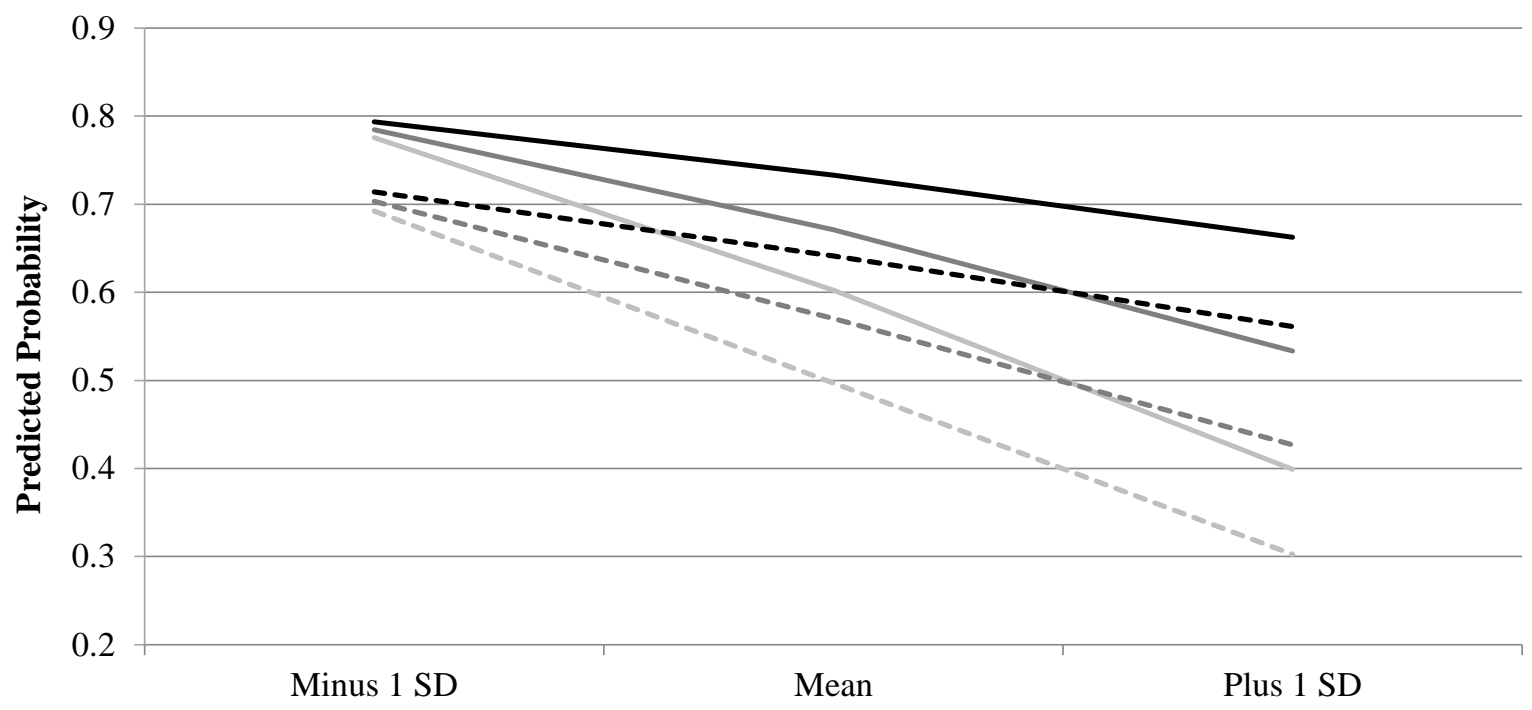

Religious Service Attendance

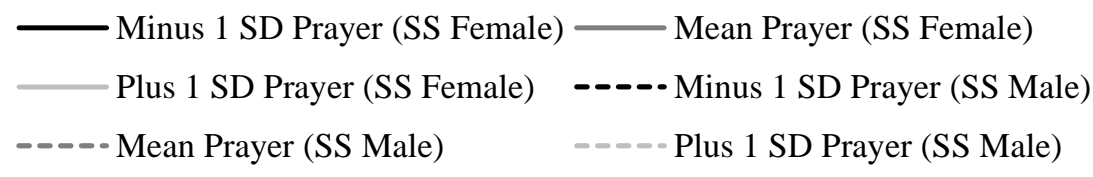

Figure 2: Predicted Probability of Agreement that Same-Sex Couples Raise Children as Well as Male-Female Couples by Religious Service Attendance and Biblical Literalism

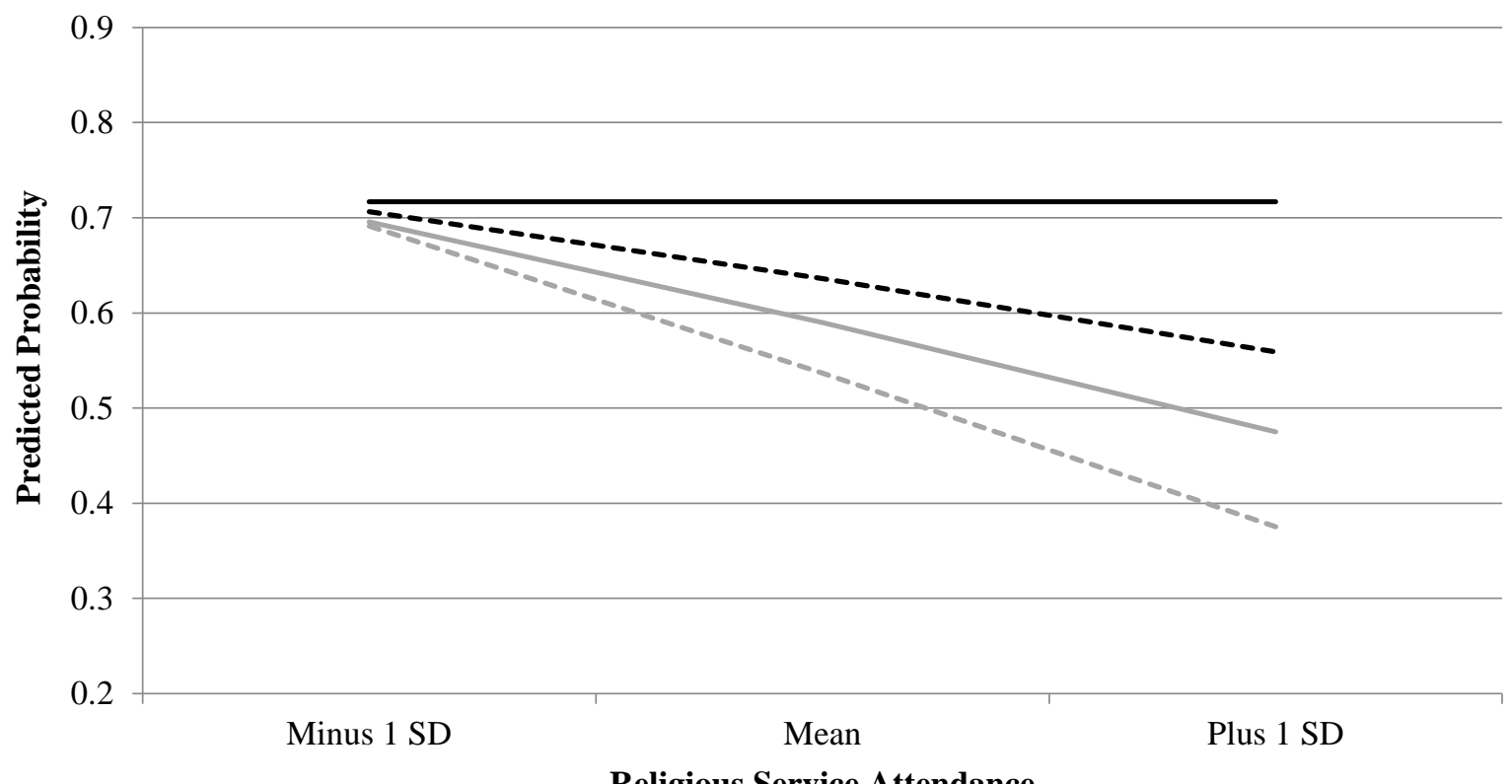

Religious Service Attendance

- Not a Biblical Literalist (SS Female) $\_$Biblical Literalist (SS Female) 
Figure 3: Predicted Probability of Agreement that Same-Sex Couples Raise Children as Well as Male-Female Couples by Religious Service Attendance and Viewing the Bible as Inspired

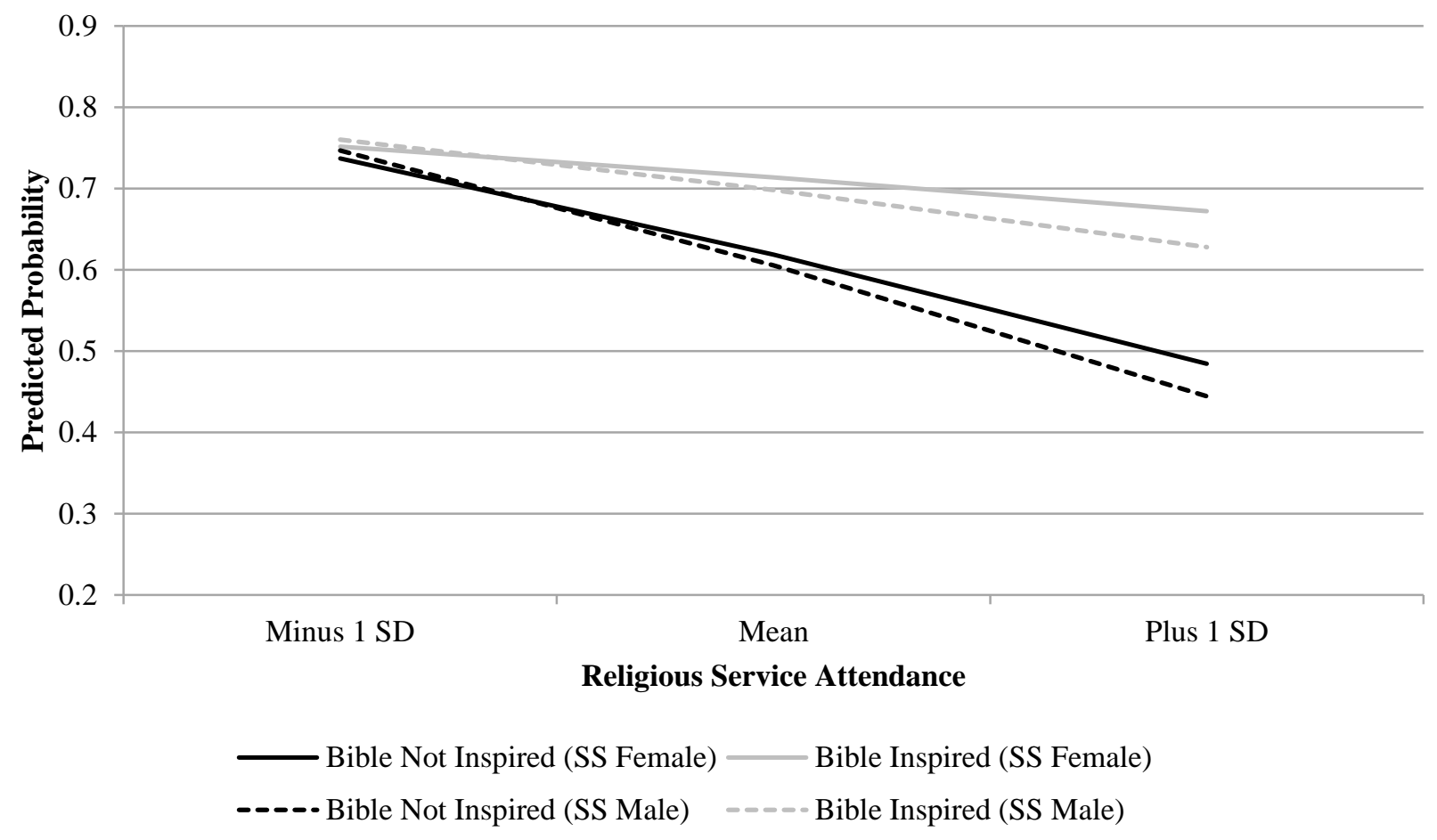

